Territorial implications of criminality and religiosity in Caracas's barrios

Dr. Gabriela QUINTANA VIGIOLA

School of Built Environment. Faculty of Design, Architecture and Building. University of Technology Sydney, Australia

Email: Gabriela.quintana@uts.edu.au

Staff page: https://www.uts.edu.au/staff/gabrielamarian.quintanavigiola

LinkedIn: www.linkedin.com/in/gabriela-quintana-vigiola-4814b71a 


\section{Territorial implications of criminality and religiosity in Caracas's barrios}

In Caracas's barrios, criminal and religious activities accompanied by flexible community dynamics influence residents' social construction of their territory. This article presents how these activities continuously reshape conceptualizations: the public, private, community and spatial boundaries of barrios. By applying a qualitative approach to interpreting participants' perspectives, the relationship between criminality and religiosity, and their link to territory are analysed. The study shows that criminal gangs privatize barrio public spaces, and that through Catholic processions those spaces become public again, thus demonstrating the temporality and flexibility of the public-private and territorial conceptions.

\section{Introduction}

Barrio is the Venezuelan term for an informal settlement. This paper presents a critical reflection on the flexibility and temporality of the urban space public-private boundary in Caracas' barrios, focusing on public spaces and how they are temporarily privatized or made public depending on the activity taking place. This discussion is based on empirical evidence arising from barrio residents' accounts of their social constructions on how criminal gangs and Catholic processions interact to shape appropriation and territorial conception of the space.

The link between criminal gangs and religiosity has been largely studied primarily from criminology and social perspectives using experimental methods, case reports, or descriptive analysis (Johnson and Jang 2011; Johnson and Schroeder 2014; Heaton 2006; Johnson 2014). Most of these investigations indicated the inverse relationship between increasing crime and greater religiosity. However, several studies showed that there is no meaningful relationship between these two variables, and only a few found a positive relationship between religiosity and criminal activities.

Despite religiosity and criminality being the subject of previous research, the 
relationship of these phenomena and the territorial implications that they create in conjunction have not been addressed, even less focusing on informal settlements.

The current investigation of territory is part of broader research on place-making through Catholic processions, important cultural events in Caracas's barrios. How residents shape and conceive their territory is closely linked to their social constructions of their urban space and the social construction of that space within a barrio is highly influenced by the activities that take place within it. Along with everyday activities-such as play, street markets and gatherings-criminal and religious activities can also reshape understandings of territory, whether in psychosocial terms (public or private), or in terms of communal and spatial boundaries.

\section{Caracas's barrios, criminality, and Catholicism}

Venezuela hosts 28 million people, of which $89 \%$ live in cities; almost 3 million people reside in Caracas, its capital city (Instituto Nacional de Estadística 2013). About 50\% of Caracas's population live in barrios, occupying around $25 \%$ of the city area (Brillembourg and Klumpner 2010; Cilento 2002; Silva, Caradonna, and Galavis 2016). Their morphology is mostly shaped by their steep topography, defined by Dovey and King (2011) as escarpments illustrated in Figure 1. 


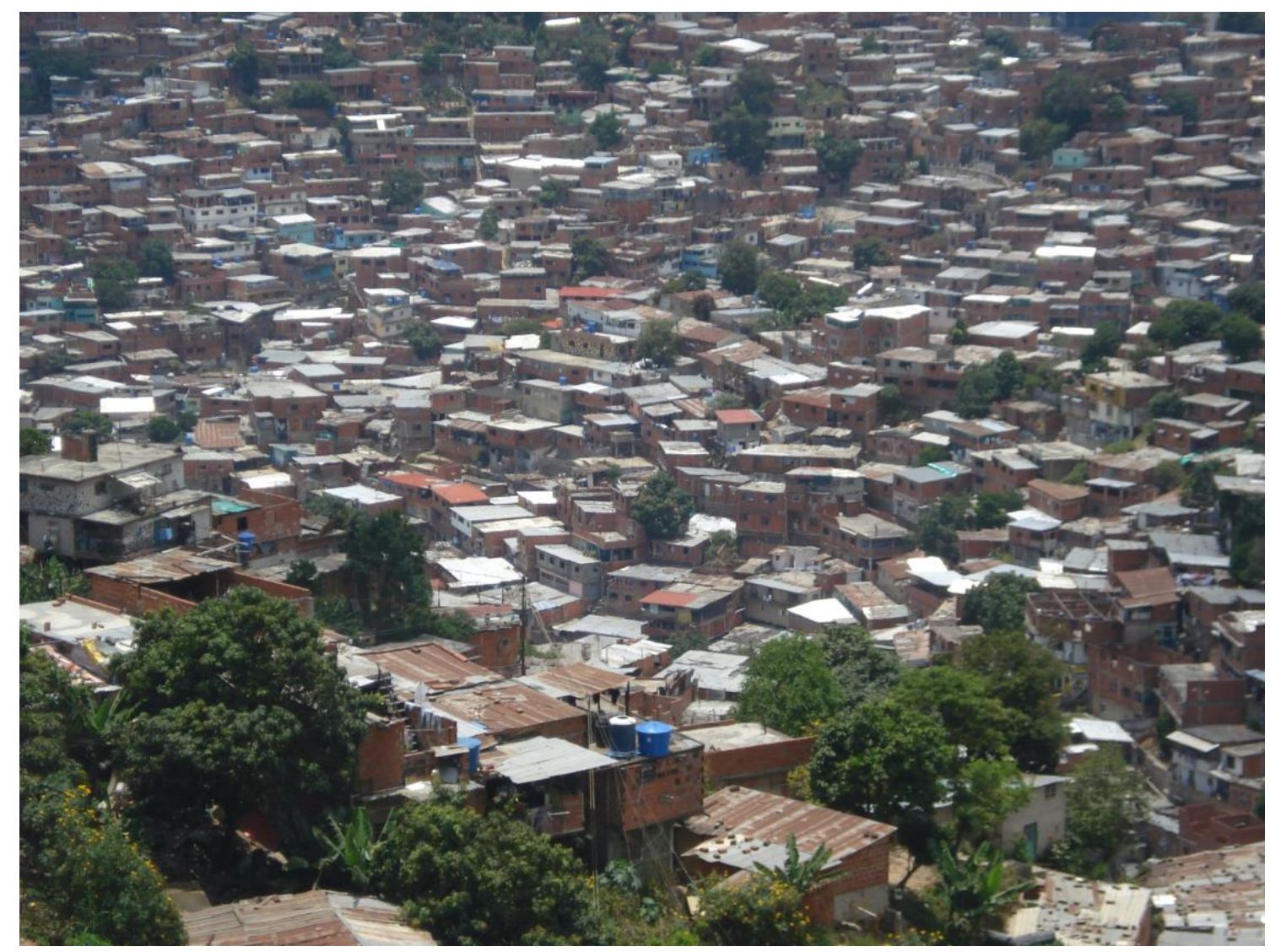

Figure 1: Barrio urban fabric - view of Julián Blanco. Source: Gabriela Quintana

Vigiola, 2009

\section{Urban space in informal settlements and in Caracas's barrios}

Urban spaces and their social significance comprise the physical spectrum, the activities that happen there, and the meanings given to spaces (Löw 2013; Maines 2000; Gustafson 2001; Manzo 2005; Ujang and Zakariya 2015; Wiesenfeld 2001; Kudryavtsev, Stedman, and Krasny 2012; Hay 1998; Relp 1976; Tuan 1977; Cresswell 2004). Interactions between private and public spaces contribute to the construction of place (Madanipour 2003).

Borja and Muxí (2001) argue that public spaces embed a socio-cultural dimension as they are 'a place of interaction and identification, of contact between people, urban entertainment, at times of community expression' (47). Public spaces enable familiarity of encounters, and of people engaging in communal activities such as festivities and 
celebrations (Kostof 1992), which ultimately stimulate social relationships and sense of belonging (Borja and Muxí 2001). On the other hand, private spaces are not for engaging with others, they encourage separation from less predictable encounters of the public space (Sibley 2005).

Depending on the culture, religion and socio-economic context, public and private spaces have different roles in communities. For example, the access of males and females to Western-defined public spaces is different from that in public spaces of Muslim (nonWestern) societies, where women have limited access to public spaces mostly used by men (Mazumdar and Mazumdar 2001). Another example lies in some impoverished neighbourhoods where social segregation is found, in which activities that are acknowledged by 'white people' as private, such as drinking, are incorporated and extended into the public space (Sibley 2005).

Over the past decades, urban spaces in informal settlements have been the focus of a wide range of studies in the urban design and planning contexts. Public and private spaces in informal settlements have been built over time through enormous effort and emotion (Lombard 2014; Bolívar and Pedrazzini 2008; Sosa Abascal 1993; Trigo 2008; Wiesenfeld 1997, 1998, 2001; Hernández García 2013). Like informal settlements all over the world, barrios in Caracas originated from people's primary need for shelter (Gilbert 1998; Turner 1976). From squatting land, people initially developed flimsy shacks called ranchos, which evolved over time into brick houses (Rosas Meza 2009). Aside from community facilities, such as schools and chapels, barrio residents eventually built infrastructure such as roads, walkways, basketball courts, piping and sewage systems, with their own resources and occasional help from the state (Gilbert 1998).

Among the conceptualizations of urban spaces in Latin America, public spaces in informal settlements are often perceived as unused or abandoned, and are traditionally characterized as leftovers of private spaces (Hernández García 2013; Segre 2010). Hackenbroch and Hossain (2012) define public spaces in informal settlements as 'all space that is outdoors and outside of private housing compounds' (418). For the residents, 
their houses are indispensable (Wiesenfeld 2001); nonetheless, public spaces are also meaningful and important elements of barrio social life (Hernández García 2013). Barrio public spaces are fundamental for fostering neighbourly relationships and friendships and for enriching residents' cultural lives (Brillembourg, Feireiss, and Klumpner 2005).

Barrio residents' social lives, and consequently the social construction of their barrios, revolve around the different interactions and activities that they engage in within their barrio. According to Rangel Mora (2001), private and public spaces are closely related to people's activities and cultural values. Thus, the concepts of 'public' and 'private' in barrios go beyond mere physical openness or accessibility (Benn and Gaus 1983). People play, gather, talk, eat, drink, and conduct religious, political, and community activities in open spaces within informal settlements (Hernández García 2013). In these public spaces, everyday activities, including criminal and cultural, take place.

\section{Criminal activities, gangs, and territoriality}

Caracas is considered one of the most dangerous cities in the world (Consejo Ciudadano para la Seguridad Pública y Justicia Penal 2015), with a murder rate of 104 murders per 100,000 inhabitants (Observatorio Venezolano de Violencia 2017). In 2006, in some barrios in Venezuela, people experienced three to four shootouts every week, leading residents to stay home after sunset because of the high risk of being killed (Greatorex 2016).

Criminality rates in Venezuela are directly related to gang activity. Criminal gangs have emerged within the barrios as a result of factors such as poverty cycles, an attitude of impunity regarding the law, perceived lack of opportunities due to poor employment rates and quality of education, growing up in an environment of violence, and rejection and, in some occasions, abandonment by families (Benda and Toombs 2000; Briceño-León 2007, 2008; Briceño-León, Villaveces, and Concha-Eastman 2008; 
Cedeño 2013; Moreno 2011b, a). Almost 90\% of Venezuelans lived in poverty in 2018, mostly concentrated in urban areas, where employment is mostly informal due to few formal job opportunities (Hagan 2018). As a consequence, some barrio residents turned to criminal activities to sustain their families, resulting in high levels of violence and fear.

The police will not enter $(\ldots)$ the drug lord rules with a gun and the culture of violence is supreme. Gangs are the normative force, and fear is king (Brillembourg 2004, 81).

Violence and criminality in barrios are directly related to the different gangs that reside in and rule specific barrios (Moreno 2009), which lead to territoriality and other community- and place-related sentiments. Criminal activities in barrios are engaged in by both men and women. However, these activities are mostly the domain of young males aged 10 to 25 years (Bannister, Kintrea, and Pickering 2013; Moreno 2011b; Rodgers and Baird 2016). These youth gather mostly in public spaces such as basketball courts. Although gang members use these spaces to play sports, they also appropriate them (and other public spaces) for other activities: (1) milling around and scheming; (2) shootouts, and (3) drug dealing (Cavalcanti Rocha Dos Dantos 2007).

As established social groups, gangs make a public claim to the space and assert territorial power. They tend to occupy and control a territory, as well as the neighbourhood, through their strength (Ley and Cybriwsky 1974), and 'territory' is fundamental to gang members' identity (Bannister, Kintrea, and Pickering 2013; Kintrea, Bannister, and Pickering 2010; Pickering, Kintrea, and Bannister 2011; SánchezJankowski 2003; Valasik and Tita 2018) and their relationship with the place and the community (Valasik and Tita 2018; Zubillaga 2007). Gangs' internal and territorial organization determines not only how they behave but also how other community 
members live and interact with each other and their urban space (McLean et al. 2018; Ralphs, Medina, and Aldridge 2009; Zubillaga 2007, 2013).

Criminal gangs mark their territory by choosing a public space, determining it as 'home' using both physical and symbolic barriers (Pickering, Kintrea, and Bannister 2012). Gangs have strong ties to the territories in which they operate, which have definite (but sometimes invisible, yet acknowledged) boundaries (Bangerter 2010; Brantingham et al. 2012; Briceño-León 2007; Herrera Rodríguez et al. 2016; Sotomayor 2016; Valasik and Tita 2018).

Barrio residents make sociocultural borders a fundamental structure of their social lives through their constant reinforcement, so that the borders become embodied structures over time (Cavalcanti Rocha Dos Dantos 2007). These sociocultural boundaries are 'socially produced imprecise, indeterminate and sometimes contested framings of social or cultural features' (Haselsberger 2014, 512). Gangs' territorial boundaries belong to this category. Gangs' lives 'are woven into the larger social fabric of the neighbourhoods, social networks, families, and friends' (Papachristos et al. 2015, 627). This type of border usually determines the group's commonalities and protects their interests, thus enhancing members' sense of belonging. It is also a control mechanism, highlighting the group's identity through segregation of the 'others' (Haselsberger 2014; Bannister, Kintrea, and Pickering 2013; Pickering, Kintrea, and Bannister 2011).

Gang territoriality is a form of 'learned behaviour with intergenerational adherence to historical boundaries and rules of engagement' (Pickering, Kintrea, and Bannister 2012). A gang's territorial boundaries originate from usage of and attachment to a space (Bannister, Kintrea, and Pickering 2013; Brantingham et al. 2012). These territorial boundaries reflect power and control (Brantingham et al. 2012). Frequently, territory is also associated with the place where the gang members were born or raised, 
or where they lived at the time of their initiation into the gang (Valasik and Tita 2018; Zubillaga 2013). Consequently, the territory expands from the gathering place to the whole barrio where they live, which is the case in Caracas's barrios.

\section{Catholic expressions in informal settlements}

Over $80 \%$ of Venezuelans are Catholics (Aguirre 2012; Ontario Consultants on Religious Tolerance 2015; Pollak-Eltz 2006, 1992). Catholicism is central for people's cultural and value systems, transmitted from generation to generation (Marzal 2002, Trigo 2008).

Other religious expressions can be found in barrios, such as the Jehovah Witnesses and Christians (also known as Evangelics); however they represent the minority (Aguirre 2012). On the other hand, the María Lionza cult (Canals 2018) and Santería (Brillembourg 2004) are highly significant in barrios. As Brillembourg (2004, 81) stated:, 'animism is widespread. The culture of magic - curanderos, or shamans, taken from rural societies - become the arbiters of the community'. It is important to highlight that these Venezuelan cults are a mix of African cults and Catholic traditions, and most members consider themselves Catholics (Tweed 1997). Thus, this paper focuses on Catholicism as a common thread between most residents, including gang members (Trigo 2008).

Catholicism features different ways in which believers express their connection to God (Collinge 2006): people may keep altars in their homes, and teach their children prayers (Pollak-Eltz 1992). At the community/social level, barrio residents often get together to build shrines at key locations, which demarcate events or places that hold special significance for the community.

People attend official everyday rituals, such as mass, and participate in occasional events such as baptisms and attending children's First Communion (Pollak-Eltz 2006; Collinge 2006). Religious processions are among these annual rituals (Flores 1986). 
Processions bring the community together to venerate a saint or Jesus and people take over the streets so that the streets become sacralized-blessed by the sacred image and the priest.

Throughout the year, processions, linked to different saints or events are organized, such as La Cruz de Mayo (Brillembourg, Feireiss, and Klumpner 2005), San Juan (Fernandes 2012), and Holy Week (Pollak-Eltz 2006; Trigo 2008, 1989). Barrio processions differ, however, some processions, such as those of the Holy week are hosted by all the barrios.

By incorporating barrio residents' perspectives, this paper provides a novel approach to understand how they define and socially construct their urban spaces. In giving barrio residents a voice, this paper contributes towards breaking the predominance of colonial approaches in understanding important urban areas (Varley 2013).

\section{Methodology}

This study adopted a qualitative approach to a case study research design; it aimed to deepen understanding of the social construction of urban spaces and territoriality in barrios through an analysis of residents' activities and experiences. The case study was selected based on two main criteria: (1) urban morphology: the area chosen for the case study had to have the urban form of a Caracas informal settlement, and (2) personal safety: Venezuelan barrios are dangerous places for outsiders, so this criteria was about having a previous relationship with a community member or person with a deep connection to the barrio to gain safe access to the place.

Participant observation and in-depth interviews were applied in the investigation of the barrio space and the residents' activities and territorial social constructions. Engaging in participant observation created a rapport with the participants, allowing for 
complete immersion in the barrio and procession experiences, recorded in the field notes. In-depth interviews allowed for comprehension of the different activities and the participants' social constructions of space, territory, and religiosity. These interviews were conducted in Spanish, the native language of the participants; the quotes presented in this article were translated into English with consent from the participants.

A total of 38 community participants took part, including priests and the lay organizers of the processions. Critical analysis and interpretation of the participants' accounts regarding their experiences linked to this topic shed light on the different layers constituting the barrio space.

Petare, located on the hills to the east of Caracas, is one of the largest barrio complexes in Latin America (Silva et al. 2016). Based on the criteria of morphology and personal safety, three areas in Petare were selected: (1) El Nazareno, (2) La Dolorita, and (3) Julián Blanco (Figure 2). Hosting the highest number of Holy Week processions was another criterion for selecting these areas. They attract participation from almost all parts of the community_including its gangs. 


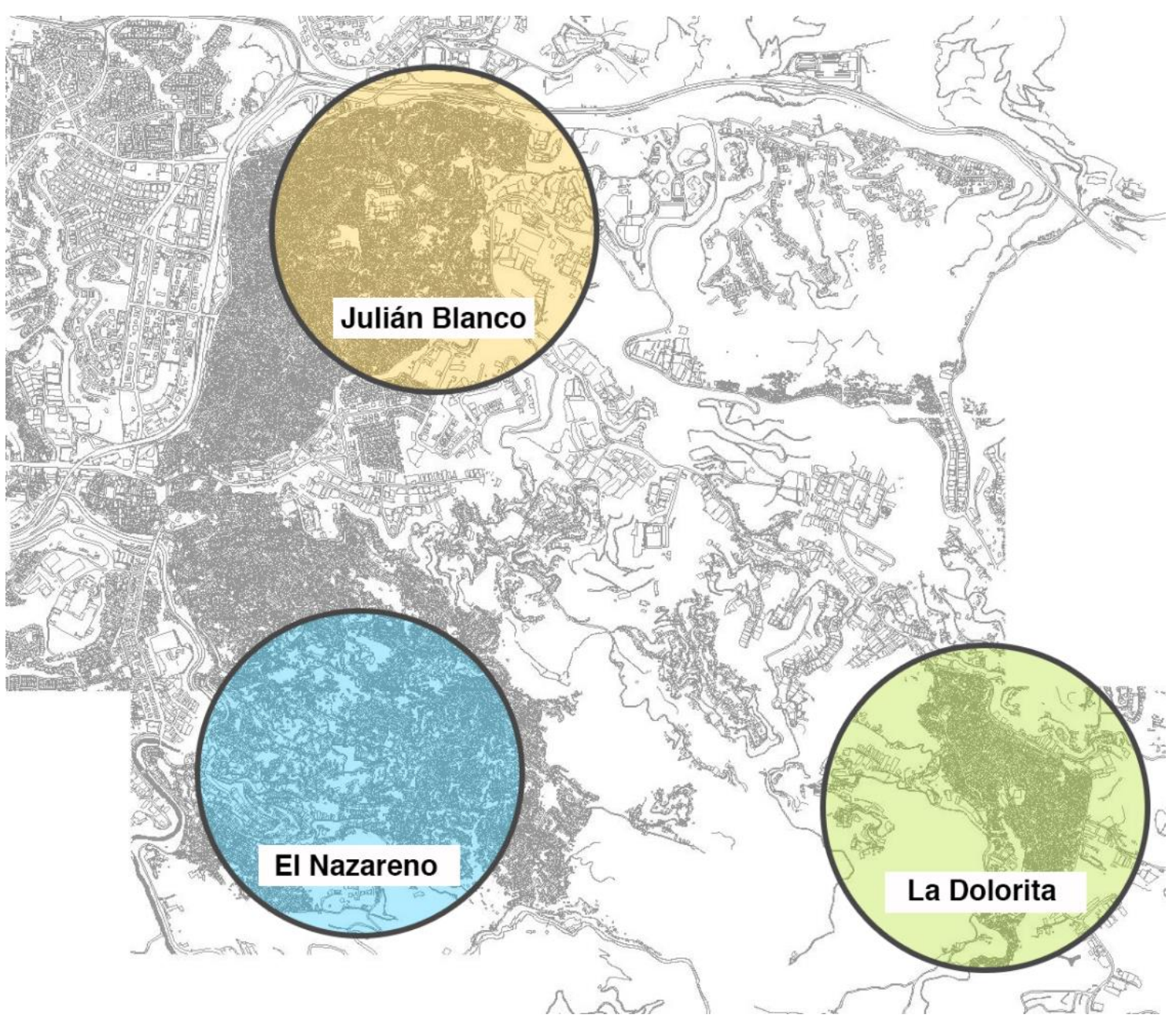

Figure 2: Selected areas of study in Petare. Source: Gabriela Quintana Vigiola adapted from the Institute of Urbanism - UCV database, 2017.

\section{Results and Discussion}

\section{Territorial implications of criminal gangs and their activities}

The territorial implications of gang activities can be articulated by analysing two themes: 1) how they appropriate and use public spaces, and 2) how they influence the community and its relationship with the space.

Appropriation and use of the barrio space

The appropriation of the barrio space is linked to use of and claims to the space; it is 
about people feeling the space as mine and recognized by others as theirs. That separation between mine and yours/theirs has social and urban impacts, as well as leading to preconceptions of the space itself. Scheming and shootouts are the two main activities of criminal gangs that participants discussed. However, they recognize that other activities engaged in by gangs are not criminal.

JM: (...) here in Julián Blanco, we have another basketball court, which is empty most of the time; it's lonely. You can see kids playing [basket-] ball on the streeteven with how hard it is to play in these streets, which are up- and downhill, and ... well, the basketball court is empty! Because they are places taken by the gangs, and the malandrosi hang out [there] and all that.

By using these public spaces - basketball courts, roundabouts, and the streets in which they live - regardless of the criminal or non-criminal activity performed, the gang appropriates these spaces. As discussed above, this psychosocial process allows them to 'define' their territory. The quote above also hints at the preconception that community members have regarding that appropriation process, because residents know that 'the malandros hang out there'. The appropriation of the space by the gang is known and respected due to fear. Thus, these become no-go areas.

JM: (...) there is this basketball court that is the most emblematic one, the famous Parquecito. (...) people [local residents] just hear about it and say that they don't even want to walk by it (...) because it has too many stories. It's almost the centre of the gangs of the area! There are a lot of stories of... people that have been murdered in that place $(. .$.

In appropriating barrio spaces, the gangs create a new delimitation of 'public' and 'private' thus forming a new social construction of territory within the community, because in reality not everyone can use all the public spaces. This sense of gang ownership exists within the community's collective mindset on a psychosocial level. 
Y: (...) and that street, eh, people call it Evil Street (...) those kids who were the owners of the street!

The 'kids' that Y mentions were the members of a local gang where she lived. By mentioning that the 'kids' 'owned' the street, Y illustrates residents' perceptions and conceptions of ownership-based use and appropriation, how gang members unofficially decide when, how, and who uses the urban space. In this case, power is determined by the ability to take someone else's life. Therefore, these public spaces become semiprivate places ruled by self-appointed gatekeepers.

G: So, El Parquecito is used only by them [the thugs] and no one else?

Ñ: No, because, as I'm saying,... if they [the thugs] accept you, you're ok and happy; if they don't accept you, you're screwed (...)

The publicness of open spaces in the barrio are determined by the possibility of using them, which strongly influences how the community relates to the spaces and the meanings associated with them. This situation also influences the community's conception of their territory.

The influence of criminal gangs on the community and their relationship with the urban space

Criminal gangs and their appropriation of public spaces effects how communities relate to the urban space in which they live, and that in most cases, they built. During the interviews, key participants expressed how they and other residents associated their feelings of fear of gangs with their feelings about related places, regardless of their original positive emotions and relationships.

$\tilde{\mathrm{N}}:(\ldots)$ it used to be a good park! ${ }_{\mathrm{ii}}$ I used to go around that area to visit some friends (...) about 5 years ago ... but lately, there are too many malandros there. They kill each other! I mean, the gangs! (...) In fact, when we arrived at the 
basketball court, the lady [another female participant in the procession] said: "no, let's go because they are going to shoot us!'

In Caracas's barrios, people have transferred their fear of thugs or gangs to the related urban space, leading the community to associate that specific space with adverse characteristics. This collectively constructed negative meaning leads to the stereotyping and stigmatization of the spaces themselves, greatly affecting people's everyday lives because it leads them to avoid using these spaces.

Y's quote above exemplifies how residents stigmatize and categorize an urban space as negative. The negative emotions and fear that residents felt towards the thugs and shootouts were transferred to that space—'Evil Street' — where 'those kids' hung out and where criminal activities happened. This emotional transferral process transcends any positive feelings that the dwellers may have originally associated with that urban space, which, in barrios, is usually a positive attachment to place (Hernández García 2013; Távara and Cueto 2015; Wiesenfeld 2001).

Criminal gangs influence how community members relate to their spaces, as the community gradually adopts the unspoken (yet acknowledged) territorial boundaries of the gangs. These mostly intangible boundaries are very real and inviolable. For gang members, the consequences of challenging these territorial boundaries are usually fatal.

Q: I swear they must have their rules (...) And they respect them! And the moment you don't respect that decision, you're in for it... you're screwed, and that's it! (...) I mean, I've seen people telling the kids, 'Don't go that way because, you know, that's forbidden territory for you' (...)

All community members in the barrio know the thugs' territorial boundaries. These 'forbidden territories' and their boundaries are by extension very real to other community members. Residents' fear extends to gangs from other barrios, and residents often fear that other thugs might harm them just for living in the 'enemy' gangs area. 
Thus, the fear of being killed for 'crossing' into gang-restricted areas causes residents to adopt the territorial boundaries set by gang members. Consequently, residents limit their movement into neighbouring barrios.

$\mathrm{L}:(\ldots)$ there is fear of moving from one area to another, simply because there is a quarrel among the gangs. Then [we think, 'As I'm from this area, even though I'm not involved in the gang, it's likely that, after knowing that I'm from there, they, well, do what they... they kill me or whatever.' So there is this fear in some areas. There is no movement, except for doing necessary stuff, and then they [people] return.

Residents move through or go to other neighbouring barrios only if necessary. Aside from unavoidable tasks, residents stay within their barrio. These unspoken or intangible boundaries are mostly psychosocial constructions created by the community. Furthermore, this process is, another way in which criminal gangs privatize the public space. This limitation (privatization), initially determined by gangs, affects residents' social construction and use of public spaces.

\section{The territorial implications of Catholic processions in barrios}

For Catholics in Petare, the Holy Week processions are the most important of the year. In several interviews, people highlighted how these are particularly meaningful events because they celebrate the life and death of Jesus. Additionally, people connected Jesus' experience to their own violent contexts. During this period, community members take over the streets of the barrio, which are flooded with people attending the three main Holy Week processions: Palm Sunday, the Nazarene procession on Holy Wednesday, the Way of the Cross and the Holy Sepulchre on Good Friday. When these processions take place, the residents' psychosocial construction of territory and its uses changes; the participants appropriate their urban spaces and transform their relationship with them 
and the whole community, thus 're-signifying' it.

\section{Appropriation and use of the barrio space}

Catholic processions in barrios are traditional in nature, and as such they have predetermined routes. Decades ago, community organizers and the clergy agreed upon what paths to use when the processions first began, and these have remained unchanged. If there are modifications to the route, these are usually minor, and driven by the community.

As the main purpose of processions in barrios is to sacralize the barrio spaces, evangelize, and bring the community together through a common cultural event, the agreed-upon paths transcend barrio limits, and are often expanded to include different areas and communities. These communities become 'one community' in a particular urban space during the processions.

D: [The] procession is a way of inviting neighbours... inviting all the people in the community, to live our faith (...)

Through these procession paths, the barrio boundaries are transcended and residents' social construction of territory is reshaped.

B: [about processions] it's not just a walk with an image through the streets (...) it's Jesus himself with his body, soul, blood, and divinity... conferring his blessings on the streets of the community.

This process of sacralization affects both the streets and gathering spaces. When the procession takes place, the residents are able to freely walk through, use, and thus appropriate all the barrio spaces. For that period of time, the territory belongs to the community as a whole. 
$\tilde{\mathrm{N}}$ : But yes! It's different! (...) I feel that that street is always the same, but on that day [of the procession], [it is] more! [On] that day, [it] is more mine! More of our people's! (...) it's more everybody's!

The influence of religiosity on the community and their relationship with the urban space

Catholic processions are meaningful activities that permeate both community relationships and how people use and conceive their spaces. Though it may sound trite, it is important to acknowledge that gang members are also people and barrio residents. Being Venezuelan and sharing the culture, gang members are also Catholic, and this influences them to interact with religious and community spaces and activities. When Catholic processions take place, the community members unite and become one; the fear of gang members temporarily ceases, and the gang members become an integral part of the community.

Gangs members tend to either withdraw from the spaces they usually use and share them with the community or get involved with the religious activities. As L mentioned: 'one of these thugs (...) came with his purple hatiii, and he (...) carried [the image]!' Carrying Jesus' image is about penitence and devotion to God. At a social level, by understanding that gang members are also Catholic, the community accepts their participation in the religious activity, and the fear they constantly feel everyday diminishes while the procession takes place.

Consequently, the psychosocial privatization of public spaces enforced by criminal gangs also vanishes for this period of time. Thus, during the Catholic processions, the urban spaces become really 'public'.

JM: So, people were concerned to know how it [the procession] was going to be on (Good) Friday; they said: (...) 'But it ends at El Parquecito, doesn't it? Because it always finishes there!' 
Therefore, the religious activity has the power to shift both the private-public distinctions and power relationships. Gangs temporarily lose their exclusive power over the space gained by the community—in conjunction with the Church. The community members' claiming and re-appropriating particular urban spaces as a vital part of their tradition is an expression of their sense of belonging and place; furthermore, it is an illustration of how territorial constructions can be reshaped, making a privatized space temporarily public. El Parquecito, the basketball court in Julián Blanco, is occupied 364 days a year by the local gang; however, on Good Friday, this area shifts from being a feared privatized space to a public community space used for the Catholic procession. In Julián Blanco, the community meaning assigned to the basketball court temporarily changes from 'fearsome' to 'safe'.

JM: The only ones who complained [about going to El Parquecito were the people from] San Judas (...) [W]ith a frightened face, they say no!, [B]ecause the gangs have issues (...) however, they come to the procession (...) [, saying] 'Let's go to the procession!'

Although some people still fear going to the gang-occupied spaces, they attend the procession because, for that specific activity, the community re-appropriates the space. The loosening of those psychosocial boundaries is partly related to how the gangs use and interact with the space when the procession occurs. The changes in these psychosocial limits consequently change how people relate to the space, thus influencing their social construction of 'their' territory.

Therefore, the gang's boundaries adopted by the residents - that prevent them from walking from one sector to another-disappear during such religious events. The only people who still cannot move freely between barrios are the thugs. 
L: [commenting upon what a gang member said to him] Ah! But the thing was [that he said,] '[W]ell, I'll walk with it from here to San José and from San José to here, but from this point forward, I cannot go.' Because he had snakesiv...

This quote highlights two relevant aspects: (1) as mentioned, thugs attend and participate in processions like other community members, and (2) thugs must always obey the territorial boundaries - without exception. During the procession, the gang members are welcome to be part of this peaceful and shared event, and just like other participants, they walk, carry the image, and spend time with the community. However, they never cross their own gang's territorial boundary.

\section{Conclusion}

This paper established how residents socially construct their urban spaces and territory through everyday criminal and religious activities. When thugs appropriate and claim public spaces, they privatize it, and the community can no longer use it freely. On the other hand, when religious events such as processions take place, the criminal gangs yield their power temporarily to the community, allowing the public space to belong to everyone. Thus, this study's findings show that, through positive cultural activities, such as the Holy Week processions, the social construction of territory can be altered. When processions take place, the barrio residents feel free and safe to use their public spaces and to cross over into other sectors. Through the religious activity, community members transfer their positive emotions towards God and their culture to usually inaccessible urban spaces so the community's assigned meaning for the space shifts from negative to positive.

This variable public-private relationship found in the barrios indicates that there are different ways to conceptualize territory. This paper highlights that there are no specific rules for the construction of 'place' and for establishing its boundaries and 
usage, challenging traditional place-making perspectives, which highlight positive experiences. Through their culture and interactions, and both positive (religious) and negative (criminal) activities, the residents constantly redefine what and when space is truly 'public' and 'private'. By listening to residents' voices (Varley 2013), this paper provides a new way of understanding territoriality in informal settlements. In barrios, the resident-space relationship is a continuum that can become fluid over time, changing because of activities and community relationships.

The relationship between gangs and religious activities and their claims on the space could often be seen as opposing and in competition. However, this paper demonstrated that they share space instead of competing for it, leading to a flexible relationship between the barrio community and their urban space. By understanding residents' perspectives on the link between activities of criminal gangs (deemed negative) and the religious events (deemed positive), comprehension of the publicprivate flexible boundaries and the construction of territory in informal settlements may be enhanced.

\section{Acknowledgments:}

I would like to acknowledge all the participants who volunteered their time to make this research possible. I would also like to thank Professor Heather MacDonald who provided meaningful feedback for the development of this research and this paper. In addition, I would like to acknowledge the reviewers of the paper for their feedback, which helped create this final version.

\section{Funding:}

This work was supported by the Australian Government Research Training Program Scholarship. 


\section{Disclosure statement:}

There is no potential conflict of interest to report.

\section{References}

Aguirre, Jesús María. 2012. ¿Hay un proceso de descristianización en el país? Informe sociográfico sobre la religión en Venezuela." SIC 745:211-222.

Bangerter, Olivier. 2010. "Territorial gangs and their consequences for humanitarian players." International Review of the Red Cross 92 (878):387-406. doi: 10.1017/S1816383110000354.

Bannister, Jon, Keith Kintrea, and Jonny Pickering. 2013. "Young people and violent territorial conflict: exclusion, culture and the search for identity." Journal of Youth Studies 16 (4):474-490. doi: 10.1080/13676261.2012.725835.

Benda, Brent B., and Nancy J. Toombs. 2000. "Religiosity and violence: Are they related after considering the strongest predictors?" Journal of Criminal Justice 28 (6):483-496. doi: http://dx.doi.org/10.1016/S0047-2352(00)00064-7.

Benn, S., and G. Gaus. 1983. Public and Private in Social Life. London: Croom Helm.

Bolívar, Teolinda, and Yves Pedrazzini. 2008. "La Venezuela Urbana, una mirada desde los barrios." Bitacora urbano-territorial 12 (1):55-73.

Borja, Jordi, and Zaida Muxí. 2001. "Centros y espacios públicos como oportunidades." Perfiles Latinoamericanos 19:115-130.

Brantingham, P. Jeffrey, George E. Tita, Martin B. Short, and Shannon E. Reid. 2012. "The Ecology of Gang Territorial Boundaries." Criminology 50 (3):851-885. doi: 10.1111/j.1745-9125.2012.00281.x.

Briceño-León, Roberto. 2007. "Violencia Urbana en América Latina: un modelo sociológico de explicación." Espacio Abierto 16 (3):541-574. 
Briceño-León, Roberto. 2008. "La violencia homicida en América Latina." América latina hoy: Revista de ciencias sociales (50):103-116.

Briceño-León, Roberto, Andrés Villaveces, and Alberto Concha-Eastman. 2008. "Understanding the uneven distribution of the incidence of homicide in Latin America." International Journal of Epidemiology 37 (4):751-757.

Brillembourg, Alfredo, Kristin Feireiss, and Hubert Klumpner, eds. 2005. Informal city: Caracas Case. Edited by German Federal Cultural Foundation. Munich, Germany: Prestel.

Brillembourg, Alfredo, and Hubert Klumpner. 2010. "Rules of Engagement: Caracas and the Informal City." In Rethinking the Informal City. Critical Perspectives from Latin America, edited by Felipe Hernández, Peter Kellett and Lea K. Allen. New York, USA: Berghahn Books

Brillembourg, Carlos. 2004. "The New Slum Urbanism of Caracas, Invasions and Settlements, Colonialism, Democracy, Capitalism and Devil Worship." Architectural Design 74 (2):77-81.

Canals, Roger. 2018. "The mirror effect: seeing and being seen in the cult of María Lionza (Venezuela)." Visual Studies 33 (2):161-171. doi: 10.1080/1472586X.2018.1470902.

Cavalcanti Rocha Dos Dantos, M. 2007. Of Shacks, Houses and Fortresses: an Ethnography of Favela Consolidation in Rio de Janeiro. University of Chicago: Illinois.

Cedeño, Luis. 2013. Violencia y criminalidad en el Área Metropolitana de Caracas: situación actual y propuestas de acción. Caracas, Venezuela: Instituto Latinoamericano de Investigaciones Sociales. 
Cilento, Alfredo. 2002. "Sobre la vulnerabilidad urbana de Caracas." Revista Venezolana de Economía y Ciencias Sociales 8 (3):103-118.

Collinge, William J. 2006. "Christianity: Roman Catholicism." In Worldmark Encyclopedia of Religious Practices, edited by Thomas Riggs, 242-251. Detroit: Gale.

Consejo Ciudadano para la Seguridad Pública y Justicia Penal. 2015. The 50 Most Violent Cities in the World, 2014. Mexico: Consejo Ciudadano para la Seguridad Publica y Justicia Penal.

Cresswell, Tim. 2004. Place: A short Introduction. Oxford, UK: Blackwell Publishing. Dovey, Kim, and Ross King. 2011. "Forms of informality: Morphology and visibility of informal settlements." Built Environment 37 (1):11-29.

Fernandes, Sujatha. 2012. "Urbanising the San Juan Fiesta: Civil Society and Cultural Identity in the Barrios of Caracas." In Ethnographies of Neoliberalism, edited by Carol Greenhouse, 99-111. Philadelphia, US: University of Pennsylvania Press.

Flores, C. 1986. "La procesión en la religión popular andino - quechua." In Santuarios, expresión de religiosidad popular, edited by Consejo Episcopal Latinoamericano - CELAM. Bogotá, Colombia: Consejo Episcopal Latinoamericano - CELAM

García, Isabel, Fernando Giuliani, and Esther Wiesenfeld. 1999. "Community and sense of community: The case of an urban barrio in Caracas." Journal of Community Psychology 27 (6):727-740. doi: 10.1002/(SICI)15206629(199911)27:6<727::AID-JCOP7>3.0.CO;2-Y.

Gilbert, Alan. 1998. The Latin American City. 2nd ed. London, United Kingdom: Latin American Bureau. 
Greatorex, Harry. 2016. "Patronage for revolutionaries: the politics of community organising in a Venezuelan barrio." University of East Anglia.

Gustafson, P. E. R. 2001. "Meanings of Place: everyday experience and theoretical conceptualizations." Journal of Environmental Psychology 21 (1):5-16. doi: http://dx.doi.org/10.1006/jevp.2000.0185.

Hackenbroch, Kirsten, and Shahadat Hossain. 2012. "The organised encroachment of the powerful"-Everyday practices of public space and water supply in Dhaka, Bangladesh." Planning Theory \& Practice 13 (3):397-420. doi: 10.1080/14649357.2012.694265.

Hagan, J Brady. 2018. "The Benefits of Arbitration with Entities in Financial and Political Distress: ConocoPhillips and Venezuela."

Haselsberger, Beatrix. 2014. "Decoding borders. Appreciating border impacts on space and people." Planning Theory \& Practice 15 (4):505-526. doi: 10.1080/14649357.2014.963652.

Hay, Robert. 1998. "Sense of Place in Developmental Context." Journal of Environmental Psychology 18 (1):5-29. doi: http://dx.doi.org/10.1006/jevp.1997.0060.

Heaton, Paul. 2006. "Does religion really reduce crime?" The Journal of Law and Economics 49 (1):147-172.

Hernández García, Jaime. 2013. Public Space in Informal Settlements:The Barrios of Bogota. Newcastle upon Tyne: Cambridge Scholars Publishing.

Herrera Rodríguez, Jacobo, Jesica María Vega Zayas, Julio César Kala, and Ana María Chávez Hernández. 2016. "Territorialidad, poder y agresión: Constantes en las pandillas de León, Guanajuato." Archivos de Criminología, Seguridad Privada y Criminalística VII (17):31-41. 
Instituto Nacional de Estadística. 2013. Dinámica Demográfica y Pobreza Censo 2011. edited by Instituto Nacional de Estadística. Caracas, Venezuela.

Johnson, Byron R. 2014. "Religious participation and criminal behavior." In Effective interventions in the lives of criminal offenders, 3-18. Springer.

Johnson, Byron R, and Sung Joon Jang. 2011. "Crime and religion: Assessing the role of the faith factor." Contemporary issues in criminological theory and research: The role of social institutions:117-149.

Johnson, Byron R, and Curtis S Schroeder. 2014. "Religion, crime, and criminal justice." Criminology and Criminal Justice, Communities and Crime.

Kintrea, Keith, Jon Bannister, and Jon Pickering. 2010. "Territoriality and disadvantage among young people: an exploratory study of six British neighbourhoods." Journal of Housing and the Built Environment 25 (4):447-465. doi: http://dx.doi.org/10.1007/s10901-010-9195-4.

Kostof, Spiro 1992. The city assembled. The elements of urban form through history. London, United Kingdom: Thames \& Hudson.

Kudryavtsev, Alex, Richard C. Stedman, and Marianne E. Krasny. 2012. "Sense of place in environmental education." Environmental Education Research 18 (2):229-250. doi: 10.1080/13504622.2011.609615.

Ley, David, and Roman Cybriwsky.1974. "Urban graffiti as territorial markers." Annals of the association of American geographers 64 (4):491-505.

Lombard, Melanie. 2014. "Constructing ordinary places: Place-making in urban informal settlements in Mexico." Progress in Planning 94:1-53. doi: http://dx.doi.org/10.1016/j.progress.2013.05.003. 
Löw, Martina. 2013. "The City as Experiential Space: The Production of Shared Meaning." International Journal of Urban \& Regional Research 37 (3):894-908. doi: $10.1111 / 1468-2427.12022$.

Madanipour, Ali. 2003. Public and Private Spaces of the City. London: Routledge. Maines, David R. 2000. "The Social Construction of Meaning." Contemporary Sociology 29 (4):577-584.

Manzo, Lynne C. 2005. "For better or worse: Exploring multiple dimensions of place meaning." Journal of Environmental Psychology 25 (1):67-86. doi: http://dx.doi.org/10.1016/j.jenvp.2005.01.002.

Marzal, Manuel. 2002. Tierra Encantada. Tratado de Antropología Religiosa en América Latina. Navarra, Spain: Pontificia Universidad Católica de Perú. Mazumdar, Shampa, and Sanjoy Mazumdar. 2001. "Rethinking public and private space: Religion and women in Muslim society." Journal of Architectural and Planning Research.

McLean, Robert, Ross Deuchar, Simon Harding, and James Densley. 2018. "Putting the 'Street'in Gang: Place and Space in the Organization of Scotland's Drug-Selling Gangs." The British Journal of Criminology 59 (2):396-415.

Moreno, Alejandro. 2009. "El malandro y su comunidad: violencia en el barrio." In Inseguridad y violencia en Venezuela - Informe 2008, edited by Roberto Briceño-León, Olga Ávila and Alberto Camardiel, 274-291. Caracas, Venezuela: Editorial Alfa.

Moreno, Alejandro. 2011a. "Educación y violencia en la Venezuela actual." Revista de Pedagogía 32 (90):119-144.

Moreno, Alejandro. 2011b. "Violencia asesina en Venezuela." Espacio Abierto 20 (1):97-130. 
Observatorio Venezolano de Violencia. 2017. Informe del Observatorio Venezolano de Violencia 2017. Caracas, Venezuela: Observatorio Venezolano de Violencia.

Ontario Consultants on Religious Tolerance. 2015. "Religions of the World: Numbers of adherents of major religions, their geographical distribution, date founded, and sacred texts." http://www.religioustolerance.org/worldrel.htm.

Papachristos, Andrew V, Anthony A Braga, Eric Piza, and Leigh S Grossman. 2015. "The company you keep? The spillover effects of gang membership on individual gunshot victimization in a co-offending network." Criminology 53 (4):624-649.

Pickering, Jonny, Keith Kintrea, and Jon Bannister. 2011. "Invisible Walls and Visible Youth: Territoriality among Young People in British Cities." Urban Studies 49 (5):945-960. doi: 10.1177/0042098011411939.

Pickering, Jonny, Keith Kintrea, and Jon Bannister. 2012. "Invisible walls and visible youth: Territoriality among young people in British cities." Urban studies 49 (5):945-960.

Pollak-Eltz, Angelina. 1992. "La religiosidad popular en Venezuela." Sociedad y Religón 9:19-32.

Pollak-Eltz, Angelina. 2006. "Venezuela." In Worldmark Encyclopedia of Religious Practices, edited by Thomas Riggs, 556-561. Detroit: Gale.

Ralphs, Robert, Juanjo Medina, and Judith Aldridge. 2009. "Who needs enemies with friends like these? The importance of place for young people living in known gang areas." Journal of Youth Studies 12 (5):483-500. doi: $10.1080 / 13676260903083356$.

Rangel Mora, Maritza. 2001. "El Carácter Social del Espacio Público en Mérida. Visión Físico Espacial." Fermentum 31:317-338. 
Relph, Edward. 1976. Place and placelessness. London, UK: Pion Limited.

Rodgers, Dennis, and Adam Baird. 2016. "Entender a las pandillas de América Latina: una revisión de la literatura [Understanding Gangs in Contemporary Latin America]." Estudios Socio-Jurídicos 18 (1):13-53.

Rosas Meza, Iris. 2009. "La cultura constructiva informal y la transformación de los barrios caraqueños." Bitacora urbano-territorial 15 (2):9.

Sánchez-Jankowski, Martín. 2003. "Gangs and Social Change." Theoretical Criminology 7 (2):191-216. doi: 10.1177/1362480603007002413.

Segre, Roberto. 2010. "Formal-Informal connections in the Favelas of Rio de Janeiro: The Favela-Bairro Programme." In Rethinking the Informal City. Critical Perspectives from Latin America, edited by Felipe Hernández, Peter Kellett and Lea K. Allen. New York, USA: Berghahn Books

Sibley, David. 2005. Private/ Public, Cultural geography: A critical dictionary of key ideas.

Silva, Elisa, Valentina Caradonna, and Odette Galavis. 2016. CABA Cartografía de los barrios de Caracas 1966 - 2014. Caracas, Venezuela: Grupossa.

Sosa Abascal, Arturo. 1993. "Barrios Humanos." SIC 56:436-439.

Sotomayor, Luisa. 2016. "Dealing with Dangerous Spaces." Latin American Perspectives 44 (2):71-90. doi: 10.1177/0094582X16682758.

Távara, María Gabriela, and Rosa María Cueto. 2015. "Sense of Community in a Context of Community Violence." Journal of Prevention \& Intervention in the Community 43 (4):304-319. doi: 10.1080/10852352.2014.973305.

Trigo, Pedro. 1989. "Evangelización del cristianismo en los barrios de América Latina." Revista Latinoamericana de Teologia 6 (16):89-113. 
Trigo, Pedro. 2008. La Cultura del Barrio. Caracas, Venezuela: Fundación Centro Gumilla.

Tuan, Yi Fu. 1977. Space and place: The perspective of experience. Minneapolis: University of Minnesota Press.

Turner, John F.C. 1976. Housing by people. Towards Autonomy in Building Environments, Ideas in progress. London: Marion Boyars.

Tweed, Thomas A. 1997. "Santería, Catholicism, and Evangelization. Struggles for Religious Identity." In Our Lady of the Exile: Diasporic Religion at a Cuban Catholic shrine in Miami. New York, United States of America: Oxford University Press.

Ujang, Norsidah, and Khalilah Zakariya. 2015. "The Notion of Place, Place Meaning and Identity in Urban Regeneration." Procedia - Social and Behavioral Sciences 170:709-717. doi: http://dx.doi.org/10.1016/j.sbspro.2015.01.073.

Valasik, Matthew, and George E. Tita. 2018. "Gangs and Space." In The Oxford Handbook of Environmental Criminology, edited by J. N. Bruinsma Gerben and D. Johnson Shane. Oxford: Oxford University Press.

Varley, Ann. 2013. "Postcolonialising Informality?" Environment and Planning D: Society and Space 31 (1):4-22. doi: 10.1068/d14410.

Wiesenfeld, Esther. 1997. "From individual need to community consciousness: the dialectics between land appropriation and eviction threat." Environment and Behavior 29:198+.

Wiesenfeld, Esther. 1998. "Entre la invasión y la consolidación de barrios: análisis psicosocial de la resistencia al desalojo." Estudos de Psicologia (Natal) 3:33-51.

Wiesenfeld, Esther. 2001. La autoconstrucción. Un estudio psicosocial del significad de la vivienda. Caracas, Venezuela: Comisión de Estudios de Postgrado. 
Zubillaga, Verónica. 2007. "Los varones y sus clamores: los sentidos de la demanda de respeto y las lógicas de la violencia entre jóvenes de vida violenta de barrios en Caracas [Young Men and Their Clamor: Senses of the Demand for Respect and the Logic of Violence Among Youth Living Violent Lives in the Barrios of Caracas]." Espacio Abierto 16 (3):577-608.

Zubillaga, Verónica. 2013."Menos desigualdad, más violencia: la paradoja de Caracas." Nueva Sociedad (243):104-118.

i In Caracas, barrio thugs are called Malandros.

ii $\tilde{\mathrm{N}}$ is referring to the basketball court 'El Parquecito', which is translated into English as 'the little park'.

iii Purple is the traditional colour associated with the procession of the Nazarene.

iv Snakes is the Venezuelan slang word for having problems with another thug or gang. Usually, it means that another thug wants to kill the person with the snake. 